\title{
RELIGIÕES AFRO-BRASILEIRAS, SINCRETISMO E REPRESENTAÇÃO TRIÁDICA DA NACIONALIDADE NO DISCURSO CATÓLICO BRASILEIRO PRÉ-CONCILIAR
}

Artur Cesar Isaia ${ }^{1}$

Resumo: Este artigo trata do posicionamento da hierarquia católica brasileira frente à representação triádica da nacionalidade brasileira, enfocando sua relação com o fenômeno do sincretismo e das religiōes afro-brasileiras. Em um período em que as religiōes afro-brasileiras conquistaram visibilidade e maior tolerância e, tanto o sincretismo quanto à representação triádica da nacionalidade encontravam respaldo em boa parte da intelectualidade brasileira, o artigo enfoca a percepção da hierarquia católica sobre esses assuntos.

Palavras-chave: Religiōes afro-brasileiras; Sincretismo; Catolicismo; Discurso religioso.

Abstract: This article deals with the position held by the Brazilian Catholic hierarchy in regards to the triadic representation of the Brazilian nationality, focusing on the relationship it had to the phenomenon of syncretism and of the African-Brazilian religions. In a period when the African-Brazilian religions acquired visibility and greater tolerance and, both the syncretism and the triadic representation of the nationality found support from a considerable number of Brazilian intellectuals, the perception the catholic hierarchy had of these issues is the main focus of this article.

Keywords: Africanbrazilian; Syncretism; Catholicism; Religious discourse.

1 Professor-Associado, Departamento de História e Programa de Pós-Graduação em História da Universidade Federal de Santa Catarina. Pesquisador do CNPq, desenvolvendo, em 2011, estágio pós-doutoral junto ao Programa de Antropologia Social da Universidade Federal do Rio Grande do Sul, sob a supervisão do Professor Doutor Ari Pedro Oro. 
Por que tão vergonhoso disfarce? Por que toda essa fachada católica? Por que santos cristãos nos terreiros pagãos da umbanda? Por que a imitação dos nossos altares, com quadros e estátuas de santos catolicíssimos?

(Boaventura Kloppenburg)

Veio, com tristeza o dizemos, veio a oficialização dos candomblés, ignominiosamente rotulados de "culto afro-brasileiro". Por que não dizer culto de brasileiros africanizados? Com isso, não é o africano que se eleva, mas é o brasileiro que se rebaixa.

(D. Augusto Álvaro da Silva)

\section{INTRODUÇÃO}

Na primeira metade do século XX, adquiriu consistência nos documentos produzidos pela hierarquia católica brasileira a representação triádica da nacionalidade, a qual vinha acompanhada da subordinação do negro e do índio à supremacia lusitana. (Isaia, 2003a) Era o que defendia Varnhagen já nos primórdios do Instituto Histórico e Geográfico Brasileiro (IHGB), ao escrever, em meados do século XIX, a sua História Geral do Brasil. O Brasil precisava de um sentido para a sua história e este passava a ser, para Varnhagen, o da consolidação da civilização sobre a barbárie de índios e

${ }^{2}$ A opinião de Varnhagen sobre o índio não contava com a unanimidade do IHGB. A este respeito, sua obra sofreu, inclusive, severas críticas. Um exemplo disso é a polêmica envolvendo Domingos Gonçalves de Magalhães, defensor ardoroso da visão "romântica da nacionalidade de viés indigenista" (Guimarães, 2002, p. 94). Magalhães defende este ponto de vista na obra Os indígenas perante a história (Guimarães, 2002, p. 94). Já a reabilitação de Varnhagen ocorreu após a sua morte, principalmente, segundo Lúcia Paschoal Guimarães, devido ao necrológio que lhe dedicou Capistrano de Abreu em 1878 (Guimarães, 2002, p. 93). 
negros, a partir da obra colonizadora portuguesa e da instauração do estado nacional, sem um episódio revolucionário que interrompesse o empreendimento lusitano. A independência sob a fórmula monárquico-constitucional resguardava o patrimônio lusitano com uma dinastia portuguesa, um monarca português, capaz de legar às gerações vindouras a herança cultural da antiga metrópole.

A hierarquia católica brasileira na primeira metade do século XX aproximou-se explicitamente da visão de Varnhagen. Nele podemos ver uma ojeriza muito grande à valorização da realidade cultural afro-indígena e, concomitantemente, um elogio sistemático à ação missionária e civilizadora portuguesa. Em um momento em que a representação sincrética da nacionalidade ganhava consistência em boa parte da intelectualidade brasileira, a hierarquia católica voltava-se para o século XIX e para meta-história de Varnhagen (Carvalho, 1992, p. 242), na qual o gênio lusitano afirmava-se como sentido civilizador e afirmador da nacionalidade.

\section{O ANTISSINCRETISMO ${ }^{3}$ NO DISCURSO CATÓLICO PRÉ-CONCILIAR}

A desvalorização do passado afro-indígena por Varnhagen é evidente, ao negar mesmo a existência de uma história dos primeiros habitantes do Brasil. Aos índios, não reconhecia nem cultura nem história. Sobre eles, dizia Varnhagen, apenas o que chamava de etnografia era possível. Introduzindo sua descrição sobre os usos e costumes dos índios brasileiros, escrevia o autor:

Para fazermos porém melhor idéia da mudança ocasionada no país pelo influxo do cristianismo e da civilização, procuraremos dar uma notícia mais especificada da situação em que foram encontradas as gentes que habitavam o Brasil, isto é, uma idéia do seu estado, não podemos dizer de civilização, mas de barbárie e de atraso. De tais povos na infância não há história: há

${ }^{3} \mathrm{O}$ termo sincretismo é usado neste texto não como categoria analítica, mas apenas como evidência empírica. Este artigo não propõe uma discussão teórica sobre o sincretismo. 
só etnografia. Nem crônica de seu passado, se houvesse meio de nos ser transmitida, mereceria nossa atenção mais do que tratando-se da biografia de qualquer varão, ao depois afamado por seus feitos, os contos da meninice e a primitiva ignorância do ao depois herói ou sábio. A infância da humanidade na ordem moral, como a do indivíduo na ordem física, é sempre acompanhada de pequenez e de misérias. E sirva esta prevenção para qualquer leitor estrangeiro que por si, ou pela infância de sua nação, pense de ensoberbecer-se, ao ler as poucas lisonjeiras páginas que vão seguir-se (Varnhagen, 1854, p. 107).

Com a valorização do escriturístico e do oficial, Varnhagen fazia eco ao elogio ao trabalho arquivístico e ao documento, condiçôes assumidas como necessárias para dar um estatuto de cientificidade à história, tanto pela escola alemã de tradição rankeana quanto pela escola metódica francesa. A presença da escola alemã na obra de Varnhagen é defendida, entre outros, por Alice Canabrava (Canabrava, 1971; 2005), Nilo Odália (Odália, 1979), José Carlos Reis (Reis, 2000) e Lúcia Paschoal Guimarães (Guimarães, 2002). Por outro lado, Temístocles Cezar, ao traçar um perfil teórico de Varnhagen, remete-o antes para uma imprecisa constelação historiográfica datada no século XIX, cujo ponto comum parece residir em ideias como imparcialidade, incansável pesquisa documental e objetividade narrativa (Cezar, 2007). Quanto ao afastamento da última característica, Cezar cita justamente um crítico de Varnhagen, Capistrano de Abreu, que argumentava a presença da subjetividade em sua obra, a ponto de recomendar que o leitor procurasse compreender o "temperamento" do autor para que a sua História Geral do Brasil se tornasse inteligível (Cezar, Op.cit, p. 162).

Fiel defensor da monarquia, da religião católica e do trabalho missionário, não é de espantar que em sua obra o índio aparecesse de maneira contingente. Aparecia em função do trabalho catequético e civilizador da Igreja, definido pelo que lhe era ausente: a uniformidade linguística, o direito positivo, as abstrações teológicas e, antes de tudo, o estado nacional. Dentro dessa linha de argumentação é que encontramos em Boaventura Kloppenburg (1961) a citação retirada de Rocha Pombo, um confrade de Varnhagem no IHGB, na qual os índios apareciam como seres infantis, carentes de proteção e empenho civilizador: 
Perseguidos de temores, agouros e preocupações cabalísticas, supersticiosos como verdadeiras crianças, sentem espíritos em toda, nos ares, nas águas, no alto das montanhas, no fundo das florestas. Uns espíritos lhes trazem avisos bons e boas notícias; outros os torturam e flagelam, e os põem num como delírio de possessos. Uns os vêem nas aragens, outros no zumbido dos insetos, ou no canto dos pássaros, ou nas colorações do poente. (apud Kloppenburg, 1961, p. 191)

Como ser contingente, o índio aparecia como um "cristão em potencial" (Ribeiro, 2010), mantendo-se no século XX a mesma carência missionária do período colonial. Neste sentido são emblemáticas as palavras contidas na Conferência Geral do Episcopado Latino-Americano, reunida no Rio de Janeiro, em 1955. Os bispos latino-americanos discutiram o trabalho missionário, sob o título Missôes, indios e gente de cor, aprofundando a alteridade da igreja do magistério frente àqueles a quem a conversão aparecia como um imperativo. Assim, louvavam

[...] o zelo apostólico com que os missionários da América Latina - seguindo o nobilíssimo exemplo de seus predecessores, dedicam suas atividades, suas energias e mesmo sua própria vida à santa empresa de incorporar à Igreja Católica a todos os habitantes das zonas que ainda constituem território de missão e manifesta a absoluta confiança de que continuarão, cada dia com maior entusiasmo esta tão apostólica tarefa. (Conferência, 1956, p. 71)

Décadas antes, em 1922, por ocasião das comemoraçôes do centenário da independência, o episcopado brasileiro lançou uma Carta Pastoral Coletiva, na qual endossava a ideia cara a Varnhagen, de uma nação unida a Portugal pela cruz. O zelo missionário aparecia elogiado pelo trabalho em trazer o Novo Mundo e seus habitantes para a cristandade ameaçada na Europa. Para os bispos, era necessária a continuação do trabalho missionário no século XX.

Apenas descoberta nossa querida pátria, sobre ela desceram a 26 de abril e no dia $1^{\circ}$ de maio de 1500 , as bênçãos de Deus pela oblação do corpo e do sangue de Jesus nas aras improvisados pelo zeloso frei Henrique de Coimbra ante o gentio estupefato! Qual pavilhão protetor no solo ainda virgem do 
Brasil ergueu-se a mandado de Pedro Álvares Cabral, em Porto Seguro, majestosa Cruz, feita de madeira das soberbas florestas da nossa terra. Ei-lo o descobridor do Brasil, levantando para perpétua memória da posse divina o glorioso padrão que há vinte séculos marca as conquistas do Filho de Deus. A Ele, pois, pertence desde a sua origem, a Terra de Santa Cruz. (Episcopado Brasileiro, 1922, p. 04. Sem marcas no original)

A nacionalidade brasileira confundia-se com o empreendimento lusitano, enquanto que os primeiros habitantes da terra, ao assistirem estupefatos à primeira missa, eram remetidos à total alteridade. $\mathrm{O}$ próprio termo gentio remetia exatamente a não civilizado, a herege, a pagão, portanto, reforçavase a necessidade da conversão e da civilização.

Os bispos tentavam criar uma "essência católica" para o Brasil, tornando óbvia a identificação entre seu povo e a igreja. Dentro desse jogo discursivo, claramente apelam para um sentido prescritivo, próximo ao que Bourdieu faz menção ao reelaborar, através da ideia de rito de instituição, a noção de rito de passagem, conforme aparece em Gennep e Turner (Bourdieu, 1996, p. 97 e segs.). Assim, os bispos tentavam "fazer ver a alguém o que ele é", ou seja, tentavam prescrever aos brasileiros um projeto identitário, no qual toda e qualquer "irrealidade pagã” cedesse lugar, pela conversão, à civilização da qual eram portadores os conquistadores ${ }^{4}$. O gentio deixaria essa condição e estaria habilitado a ser brasileiro e civilizado, na aceitação do catolicismo

Afinado com a representação cara a Varnhagen, a hierarquia torna clara a "filiação" lusitana do Brasil, assumindo uma origem branca e cristã, conforme aparece na fala de D. Carlos Carmelo de Vasconcelos Motta:

Teve o Brasil cristão uma origem nobre e eugênica, filho que é e bem nascido da católica estirpe portuguesa, daqueles heróicos civilizadores e evangelizadores

${ }^{4}$ A visão romântica do índio brasileiro existente na obra de José de Alencar capta com acuidade esta oposição entre civilização e barbárie, resolvida pela conversão, no olhar do conquistador. Mesmo para um personagem como Peri, que apesar de "selvagem", ostentava características típicas da cavalaria, o batismo e a adoção de um nome português são condições necessárias para que D. Antonio de Mariz a ele confiasse a proteção de sua filha Cecília, na fuga frente ao iminente ataque dos aimorés à sua casa. (Alencar, 1979) 
"que a fé e o império iam dilatando" em cada uma de suas conquistas, através dos mares e continentes. (Motta, 1955, p. 235)

O purismo étnico e religioso herdado dos conquistadores não subsiste a uma análise histórica. Gilberto Freyre lembrava a coexistência do catolicismo com conteúdos residuais de paganismo no passado português. Este, ao contrário, seria marcado por uma pluralidade étnica e por uma plasticidade de crenças, absolutamente distantes do purismo católico e caucasiano (Freyre, 1975; Sanchis, 1983; 1995). Essa ausência de uma identidade una, no sentido étnico e cultural na propagada herança lusitana, ganha visibilidade na realidade litúrgica católica do período colonial brasileiro, em que as cerimônias religiosas, notadamente o culto externo à eucaristia, os chamados "triunfos eucarísticos" remetiam às mesmas analogias estéticas com o mundo précristão existentes desde o medievo português. (Toledo, 1990; Freyre, 1975)

Por seu turno, para a hierarquia católica brasileira, nascido o Brasil de Portugal, acrescentava-se ao seu nascimento uma predestinação, revelando a sua origem um momento originário, capaz de dar sentido a toda a sua história: a primeira missa.

A predestinação providencial do Brasil pode-se inferir do seu místico berço, que foi no regaço eucarístico da primeira missa em Porto Seguro e sob os auspícios maternais de Nossa Senhora da Piedade, que o Almirante Pedro Álvares Cabral trouxera na sua armada. (Motta, op.cit., p. 235-236)

A ideia de um nascimento providencial para o Brasil acena na direção de uma "fundação mítica", que indelevelmente deveria marcar a identidade da nação e a leitura da sua história (Isaia, 2003a). Para Marilena Chauí (Chauí, 2000, p. 9), a ideia de fundação está ligada a algo tido como perene, capaz de atravessar todo o curso temporal e anular diferenças e contradiçōes.

Os efeitos de longa duração buscados pela hierarquia católica brasileira na representação da nação cristã, que prolongava a fidelidade lusitana ao evangelho, são ratificados nas palavras do cardeal português Cerejeira durante a inauguração de Brasília: 
Continua a história do Brasil. Como na hora do seu nascimento, renova-se o santo sacrifício da redenção - princípio do homem novo e do mundo novo - ao inaugurar Brasília, a nova capital do Brasil do futuro. Nasceu cristão o Brasil. Foi em Porto Seguro o seu batismo. Serviu Portugal de padrinho. O nome que lhe deu buscou-o no evangelho (nome da esperança, da libertação, da salvação): Vera Cruz. A consagrar a terra nova, que o padre Rui Pereira, da Companhia de Jesus, em 1560 dizia que se houvesse paraíso terreal seria aqui e a redimir o homem, que Pero Vaz de Caminha acrescentava ser o "melhor fruto que dela se pode tirar" - Nosso Senhor Jesus Cristo, o redentor do mundo, veio em pessoa, sacramentalmente, na missa celebrada por frei Henrique de Coimbra... (apud Baptista, 1974, p. 21-22. Sem marcas no original)

A ideia da linearidade com o passado lusitano e cristão, cara a Varnhagen, permanece na fala de Cerejeira, ao referir-se ao projeto arquitetônico da nova capital, que sinalizava em direção ao futuro do Brasil:

E foi com o sinal da redenção do homem, cujo nome é o mesmo nome do Brasil que Brasília foi levantada. Não afirmou o seu arrojado planejador ${ }^{5}$ que a base da concepção da cidade foi o "próprio sinal da cruz"? (apud Baptista, 1974, p. 22)

Fora desse sentido prescritivo remetido à cruz, à primeira missa e ao "nascimento" do Brasil deveria ser impossível reconhecer a nação e o povo. Este instante originário deveria presidir o curso temporal da nação e do estado, "[...] sendo atualizado de maneira rememorativa”" (Isaia, 2003a, p. 252). A própria fala de Juscelino Kubitschek durante a missa de inauguração de Brasília reitera o mito fundante e a linearidade com o passado lusitano endossados pela hierarquia católica ao mostrar-se "[...] voltado para a cruz da descoberta e da primeira missa que Portugal nos confiou para este dia solene". (apud Nogara, 1960, p. 377)

${ }^{5}$ Diga-se de passagem que o "arrojado planejador" festejado por Cerejeira, Lúcio Costa era um admirador e valorizador da tradição portuguesa e de sua influência, não somente na arquitetura, mas na formação cultural brasileira. (Wisnik, 2001) 
Por outro lado, no período pré-conciliar, a identificação mítica com o passado português somava-se à representação da realeza de Cristo sobre o país, cujo reinado era proclamado solenemente nas grandes mobilizações públicas, basicamente nos Congressos Eucarísticos, conforme referimo-nos em outro trabalho:

As grandes mobilizações públicas, principalmente os Congressos Eucarísticos, onde a massa popular era vista como "súditos de Cristo Rei", a adoção de uma imagem hierática, que se representava como acima da transitoriedade do poder burguês pela hierarquia episcopal, tudo isso procurava reforçar a autoridade de uma instituição que se credenciava frente ao estado como importantíssima interlocutora, capaz de matriciar uma elaboração de imagens extremamente mobilizadora e capaz de sedimentar a coesão social. (Isaia, 2003b, p. 69)

Dessa forma, o hino do Congresso Eucarístico celebrado no centenário da independência cantava tanto a herança cristã lusitana quanto reiterava a ideia da primeira missa como momento de nascimento da nação:

Sobre os mares azuis da Bahia, Foi que outrora raiou, toda em luz, A Hóstia Santa, qual sol que alumia, O almo berço da Terra da Cruz." (Correa, 1933)

Sempre ratificando a ideia mítica de um purismo católico no passado português, ao qual o Brasil ligava-se umbilicalmente, a hierarquia, por muito tempo, não tolerava qualquer aproximação com o que entendia por sincretismo.

Assim como o primeiro habitante da terra, o negro era remetido à necessária ação missionária e civilizadora lusitana e católica. A hierarquia católica acentuava sua inserção em um interdiscurso no qual o negro, como o índio, era infantilizado, seu universo valorativo era desqualificado e suas crenças eram remetidas à superstição. Na década de 1950, frei Boaventura Kloppenburg reproduzia as palavras do Diário de Notícias, do Rio de Janeiro, segundo as quais era urgente que o negro brasileiro voltasse as costas para a África. Era, portanto, necessário "[...] destruir o que de africano persiste na sua alma e sua mentalidade, através do combate à superstição, esta última... 
a nosso ver, um dos grandes entraves à ascensão mental de nossos irmãos de cor.” (apud Kloppenburg, 1953, p. 420) A violência simbólica contida na citação anterior articulava-se na transcrição, pelo mesmo Kloppenburg, de um trecho das Constituiçôes Primeiras do Arcebispado da Bahia, promulgadas em 1707, nas quais os escravos africanos apareciam, em sua ignorância, não poucas vezes incapazes de internalizar as verdades da fé, "caridosamente" passadas por seus senhores. Sobre a catequese dos negros, dizia o documento existirem no Brasil alguns negros "[...] tão boçais e rudes, que, pondo seus senhores à diligência possível em os ensinar, cada vez parece que sabem menos." (apud Klopenburg, 1961, p. 128)

A afirmação da supremacia cristã portuguesa por parte da hierarquia não deixava de salientar o caráter épico da expulsão dos holandeses do nordeste brasileiro. (Episcopado Brasileiro, 1922). Sob o comando lusitano, as "três raças" lutam contra o "invasor herege", defendendo o poder real português. A defesa do nordeste invadido pelos holandeses é apresentada à maneira de Varhnagen, ou seja, como o prelúdio da formação do sentimento de união nacional, acima das particularidades "raciais". (Varnhagen, 1854, p. 362 e segs.)

No álbum publicado para comemorar os cinquenta anos da ordenação sacerdotal do arcebispo do Rio de Janeiro, D. Joaquim Arcoverde de Albuquerque Cavalcanti, Jônatas Serrano, figura de proa do laicato católico, publica uma poesia bastante peculiar (Serrano, [snt]). Na poesia aparecem o chefe indígena cristianizado, Arariboia; o padre José de Anchieta e o considerado fundador do Rio de Janeiro, Estácio de Sá. Serrano louva a ação militar de Arariboia ao lado dos portugueses contra os franceses aliados aos tamoios, no episódio que passou a ser conhecido como Confederação dos Tamoios. Convertido ao catolicismo, adotando um nome português, portanto, distanciando-se do seu passado, Araribóia é apresentado como um herói "elevado" a uma situação superior. Para Serrano, assim como para a hierarquia católica do período em questão, tanto o indígena quanto o negro só poderiam lograr elevação na anulação do seu passado.

Ratificando a representação triádica da nacionalidade brasileira, D. Aquino Correia, à maneira de Varnhagen, posicionava-se pela ação civilizadora 
portuguesa, capaz de coordenar as "raças" tidas como formadoras da nacionalidade, não faltando menção à expulsão dos holandeses do nordeste, qualificada como "ilíada" brasileira.

Far-vos-á ele ver no brasileiro, um povo talhado para mais severos hábitos. Os elementos étnicos que o plasmaram são todos de têmpera rija e austera. $\mathrm{O}$ índio foi um guerreiro sempre em armas. [...] Bem conhecida é a resistência sofredora do africano. E o português foi, finalmente, como sabeis, o único povo do mundo cujo heroísmo inspirou epopéia tão nacional e verdadeira como "Os Lusíadas", a que faltaria, entretanto, o segundo tomo, não menos épico e glorioso, aqui traçado por esse povo de fortes, sobre os mares e sertōes misteriosos do ocidente. E foi na luta, foi na guerra holandesa, na ilíada nacional do século XVII, que essas três raças, representadas por Poti, Henrique Dias e Fernandes Vieira, fundiram-se ao fogo das batalhas, preparando na história, o advento do homem brasileiro. (Correia, 1944, p. 163. Sem marcas no original)

Já o intelectual católico Gladstone Chaves de Melo, ao mesmo tempo em que assumia a representação triádica da nacionalidade, tinha uma opinião bem diferente sobre o negro e o índio. Para ele, nem todos os elementos formadores da nacionalidade possuíam a "têmpera rija e austera" louvada pelo arcebispo. Do indígena o Brasil herdara uma indolência e uma extrema conformação às suas origens telúricas. Era o que chamava de "nostalgia do sertão". Já do negro, o Brasil herdara uma bondade "infantil", além de uma "desregrada lascívia". Aparecia, então, o português legando a uns e outros uma "cultura requintada", capaz de comandá-los e subtraí-los do atraso. (Melo, 1947)

A ação coordenadora, missionária e civilizadora dos valores ligados à cultura superior não poderia conviver com qualquer tipo de valorização do “atraso" afro-ameríndio. É assim, que Dom Carlos Carmelo de Vasconcelos Mota, lamentava a sobrevivência da cultura negra no Brasil de meados do século XX, onde a urbanização e a industrialização aceleravam-se: "É triste averiguar que a marcha do nosso 'progresso' espiritual e cultural é no sentido da senzala para o salão.” (Mota, 1953, p. 302) 
Na mesma direção acenava D. Augusto Álvaro da Silva, inconformado com o reconhecimento legal dos candomblés e desejoso de que a Bahia retornasse a ser "como Nosso Senhor a fez", "branca e altiva":

Grande Deus! O candomblé! O candomblé na Bahia! Maldita hora em que se legitimou entre nós esta baixa e ignóbil prática de ritos africanos! [...] Quem diria? Na Terra da Santa Cruz, no Brasil dos católicos descobridores, na Bahia da Cruz Cabralina, que abrigou e protegeu a terra nova, que nascia apenas; na Bahia dos Catequistas, que arrancaram amuletos aos peitos dos selvagens entregando-lhes a Cruz de Jesus Cristo e lhes ensinando a pronunciar os nomes de Jesus e de Maria [...] pretender atribuir foros de brasilidade e de religião ao que pertence apenas ao africanismo fetichista, bronco e rude! Provera a Deus que chegasse o grito de nossa alma de pastor angustiado e aflito pedindo restrições a esta licenciosidade dos candomblés africanos na Bahia, a quantos possam influir para a cessação de prática tão contrária à fé nacional e à civilização brasileira. Pedimo-lo, em nome de nossa Constituição, em nome da higiene moral e sanidade mental de nossa gente; pedimo-lo pela Bahia sempre católica e não fetichista; pela Bahia civilizada e culta e não por uma Bahia selvagem e maninha; pela Bahia branca e altiva, como Nosso Senhor a fez, e não por uma Bahia negra e politeísta como procuram apresentá-la nos terreiros de candomblé, irmão gêmeo da escravidão africana. (Silva, 1950, p. 6-7. Sem marcas no original)

As sobrevivências "fetichistas" africanas eram remetidas, pelo frei Boaventura Kloppenburg, entre outras causas, à extrema disseminação das mesmas entre a elite branca. No começo da década de 1950, ao mesmo tempo em que deplorava a leniência das autoridades policiais e judiciárias frente ao crescimento dos terreiros ${ }^{6}$ no Rio de Janeiro, apontava como causa deste aumento, a familiaridade da elite branca com o "fetichismo africano", além da utilização dos mesmos como atrações turísticas.

${ }^{6}$ Apesar da Constituição então em vigor (1946) garantir a liberdade religiosa, Kloppenburg amparava seu argumento no artigo $141, \S 7$ da mesma Constituição, que resguardava o livre exercício dos cultos religiosos, salvo os que não contrariassem a ordem pública e os bons costumes. Igualmente, respaldava a sua argumentação no artigo 284 do Código Penal em vigor, o qual proibia o exercício do curandeirismo. (Kloppenburg, 1953, p. 417) 
Mas por que a polícia, não obstante, continua a registrar e legalizar estes antros de superstição, intoxicação e mistificação que levam tanta gente às práticas bárbaras de verdadeira idolatria e paganismo e, também, ao manicômio? O que na verdade notamos, não é apenas a criminosa tolerância; vemos mais: o Rio inteiro acha as macumbas pitorescas, elas são até mesmo incentivadas como espetáculo de valor turístico e mesmo gente de certa categoria se deixa levar pela sua religiosidade primitiva. Quando no ano passado Joãozinho da Goméia fez a festa de apresentação de suas novas "filhas de santo", lá estavam presentes, entre outros: o General Ciro de Rezende, chefe de Polícia; o General Pinto Aleixo, senador da república, senhora e filha; o Coronel Santa Rosa, representando o Prefeito do Distrito Federal, o Almirante Iracindo Carvalho Pinheiro e senhora, o Deputado Assis Maron e senhora, o Deputado Oliveira Brito, o Sr. Raul Gravatá, representante do governo da Bahia, o Almirante W. Heat, chefe da Missão Naval Americana e senhora e mais outras personalidades ilustres, conforme registravam os jornais daquele dia. E isso significa mais do que tolerar: é aprovar e incentivar tão perniciosas como criminosas práticas que vitimam a gente simples e pobre do Rio de Janeiro. (Kloppenburg, 1953, p. 417-18)

As palavras de Kloppenburg (1961), deplorando a familiaridade da elite com os terreiros, ou do Cardeal Motta, lamentando a invasão do $s a$ lão pela senzala pareciam fazer eco a Raymundo Nina Rodrigues (1939). Mesmo não desenvolvendo uma discussão sobre a questão do sincretismo, Nina Rodrigues (1939) denunciava que pairava algo de anormal sobre a sociedade brasileira, advindo justamente do contágio negro sobre os brancos (Nina Rodrigues, 1939). Além disso, outra aproximação que podemos fazer entre o discurso católico pré-conciliar e o pensamento de Nina Rodrigues diz respeito à propalada tese da ilusão da catequese (Nina Rodrigues, 1935). $\mathrm{O}$ autor maranhense, escrevendo sobre a realidade baiana do final do século XIX, defendia que, ao lado da parcial integração do negro à sociedade "civilizada", dava-se também a aceitação apenas formal do catolicismo, subsistindo o fetichismo africano malgrado à catequese. A presença deste fetichismo estava longe de concentrar-se nos negros, mas atingia difusamente toda a sociedade ${ }^{7}$.

\footnotetext{
${ }^{7}$ A ideia da crença generalizada no feitiço, atingindo autoridades policiais e judiciárias foi testada por Yvonne Maggie através do estudo de processos criminais de finais do século
} 
O posicionamento de Kloppenburg sobre o passado católico lusitano é bastante peculiar se o compararmos com o tom laudatório e ufanista da hierarquia, que simplesmente reiterava uma herança católica lusitana. Kloppenburg identificava um "catolicismo português e popular" extremamente permeável ao sincretismo afro-ameríndio. Este catolicismo caracterizava-se por uma "[...] exagerada devoção aos santos... pouco sacramental e consciente muito ligado ademais a usos e práticas supersticiosas" (Kloppenburg, 1961, p. 25). Kloppenburg não contemporizava de forma alguma com a presença dessas características na vida eclesial brasileira. Essas práticas não caracterizavam um "verdadeiro cristianismo" e mais se aproximavam do "fetichismo africano" (Idem). Por outro lado, já na Introdução de $A$ Umbanda no Brasil (1961), surgida às vésperas do concílio Vaticano II, Kloppenburg escreve que a igreja não se identifica com nenhuma cultura, portanto, que seria possível levar sua mensagem salvífica a qualquer povo. Consequentemente, poderia haver a aceitação da igreja ao passado cultural africano, desde que não houvesse a subsistência de valores que se chocassem com os ensinamentos católicos: "[...] não somos anti-africanistas, como não somos contra nenhuma cultura sã, de qualquer nação que ela seja ou a qualquer raça ela pertença ${ }^{8} . "$ (Idem, p. 06) É fundamental que se compreenda os limites desta aceitação eclesial à cultura africana. Melhor dito, é importante que reconheçamos na autocompreensão ${ }^{9}$ (Poulat, 1971; Wernet, 1987) de igreja assumida por Kloppenburg $(1960,1961)$ no final dos anos cinquenta e início dos sessenta, os limites à aceitação da diversidade cultural e à prevalência ainda da ideia de missão e de conversão. Nessas ideias de missão e conversão é que vamos encontrar a dificuldade desta "igreja do magistério"

XIX até meados do XX. (Maggie, 1992)

${ }^{8}$ Kloppenburg está referenciando-se na alocução que o Papa João XXIII dirigiu aos membros do II Congresso de escritores e artistas negros, no qual afirma que a igreja "[...] não se identifica com nenhuma cultura, nem mesmo com a cultura ocidental, com a qual, entretanto, a sua história está estreitamente entremeada." (apud Kloppenburg, 1961, p. 06)

9 Por autocompreensão de Igreja, entende-se as "[...] diversas maneiras de auto-entendimento, diversas imagens que a igreja [...] teve de si mesma”. Essas autocompreensões são “[...] marcadas pelas grandes superestruturas de cada época, seja nas suas formas institucionais, seja em sua linguagem e em seus modos de pensar." (Wernet, 1987, p. 12) 
em aceitar e conviver com uma situação pluralista. Como aceitar o passado cultural africano no Brasil despindo-o de sua base mítica, das ritualizaçōes da sua memória ancestral? (Prandi, p. 32 e segs.) Sem esse fundamento mítico, inconciliável com a autocompreensão de igreja afirmada por Kloppenburg (1960, 1961), as manifestações mais aparentes da cultura como as danças, as comidas, os gestos, as palavras deixam completamente de ter sentido, esvaziam-se, perdem o seu ethos.

Um exemplo dos limites da aceitação da cultura africana no Brasil podemos ler na resposta dada por Kloppenburg a uma questão posta por um vigário que se negara a benzer o estandarte de São Benedito, levado por um grupo de congados, concomitantemente integrantes de uma irmandade em sua paróquia. $\mathrm{O}$ padre perguntava como deveria agir em relação à congada $\mathrm{e}$ aos congados. Frei Boaventura responde que achava excelente que houvesse uma irmandade católica, cujo padroeiro fosse um santo negro. Contudo, recomendava cautela na aceitação da congada por parte da autoridade eclesiástica, já que "[...] o folclore tem sempre portas abertas para a superstição" (Kloppenburg, 1959, p. 655). O sentido que a hierarquia católica dava à palavra sincretismo era completamente negativo. Ao contrário do sentido positivo atribuído originalmente por Plutarco (Plutarco, 1844) ao termo ${ }^{10}$, a hierarquia, mesmo com o concílio Vaticano II, aproximava incretismo de desvio, contaminação ${ }^{11}$.

${ }^{10}$ Para Plutarco, os cretenses ofereciam um ótimo exemplo de sobrevivência quando punham de lado suas diferenças e se uniam ao inimigo comum, chamando esse ato de sincretismo. (Plutarco, 1844)

${ }^{11}$ Um desses momentos aparece em uma obra publicada em 1965 pelo padre jesuíta Edvino Friderichs (Friderichs, 1965). Trata-se, portanto, de um livro sobre as religiões mediúnicas e afro-brasileiras surgida em pleno "aggiornamento" e diálogo ecumênico proposto pelo Vaticano II (Isaia, 2002). Após tecer comentários sobre as religiōes afro-brasileiras e o sincretismo religioso com argumentos bastante próximos aos expostos anteriormente por Kloppenburg (1960, 1961), padre Friderichs passa a comentar o filme O Pagador de Promessas, baseado na obra homônima de Dias Gomes. Friederichs comenta, não a ação da igreja católica no presente e no passado, mas a forma como o padre é apresentado na peça e no filme. Reconhecia que o padre criado pela ficção de Dias Gomes era intolerante e que a intolerância era odiosa. A solução era muito simples para o sacerdote: bastava o "produtor" do filme esquecer o texto de Dias Gomes e apresentar um padre 
Ao mesmo tempo em que dizia ser possível "a coexistência entre cultura e religião num só cidadão”, Boaventura Kloppenburg não podia aceitar "o conúbio harmonioso de duas ou mais religiões distintas num mesmo ser racional" (Kloppenburg, 1961, p. 7). Denunciando a multiplicidade concomitante de experiências religiosas entre os brasileiros, escrevia Kloppenburg:

Partimos da averiguação de um fato: a confusão religiosa existe. E essa confusão é grande, basta abrir os olhos. E por confusão religiosa entendemos não a multiplicidade de religiōes diversas num mesmo país, mas a pluralidade de concepçôes religiosas num mesmo indivíduo. Não nos admira que coexistam pacificamente, um ao lado do outro, o catolicismo, o protestantismo, o espiritismo, a umbanda, a maçonaria, o esoterismo, etc. É o sistema de pluralismo religioso, conseqüência natural e inevitável dos princípios liberais, laicistas e racionalistas. É uma situação de fato que toleramos em conseqüência da liberdade do homem. Mas o que nos espanta e não chegamos a compreender é o fato de que várias religiōes ou concepçôes religiosas, filosóficas ou doutrinárias, diretamente opostas entre si e racionalmente conciliáveis possam coexistir, não numa nação ou numa familia, mas num só e mesmo indivíduo. (Kloppenburg, 1960 , p. 5. Sem marcas no original)

Mais explícitas ainda são suas palavras, louvando a ação pastoral do bispo de Gonaives no Haiti, Dom Paul Robert, que, no final dos anos 1940, criou uma "carteira de católico" para aqueles haitianos que abjurassem das práticas do vodu e se submetessem a um rigoroso exame sobre os artigos de fé católicos. Esta carteira poderia ser exigida pelos sacerdotes por ocasião da recepção dos sacramentos. As situaçôes haitiana e brasileira tinham, para Kloppenburg, similitudes evidentes, requerendo medidas semelhantes:

Em muitas regiōes do Brasil estamos marchando retilineamente para a situação que se criou na "católica" república do Haiti. Tivemos oportunidade de falar sobre estas questões com o Sr. Bispo de Gonaives, em Haiti, Dom Paulo

tolerante que, com caridade e paciência, mostrasse ao protagonista, Zé do Burro, que a correspondência entre Santa Bárbara e Iansã não existia, era uma mentira, vivenciada na ignorância religiosa do povo brasileiro. A verdade da igreja converteria o protagonista, Zé do Burro [...]. 
Robert. Lá existe a mesma dificuldade e confusão... grande parte dos três milhôes de haitienses é gente de cor [...] O que aqui chamam de umbanda (ou macumba, candomblé, batuque, xangô, nagô, etc.) lá tem o nome de vodu [...] Como aqui no Brasil, também lá em Haiti querem ao mesmo tempo ser católico e "voduístas". A situação, pois, é perfeitamente paralela. (Kloppenburg, 1961, p. 211)

D. Paul Robert, por outro lado, suprimiu todas as imagens de santos da catedral de Gonaives, devido ao que considerava ser o culto pagão das mesmas por parte dos seus diocesanos, concomitantemente adeptos do vodu: "[...] os santos se haviam transformado em verdadeiros ídolos. Foram supressas também a maior parte das festas de padroeiro, que não passavam de manifestaçôes pagãs sob a fachada cristã.” (Kloppenburg, 1961, p. 215)

A visão negativa do sincretismo religioso, o reconhecimento da superioridade do catolicismo, o qual não deveria corromper-se pelo contato com os valores afro-ameríndios permaneceu em épocas recentes. Ainda na década de 1970, a Conferência Nacional dos Bispos do Brasil (CNBB) publicou um pequeno livro com o resultado de várias discussões sobre as religiões afrobrasileiras, a fim de colaborar no trabalho pastoral. $\mathrm{O}$ interesse que despertou o opúsculo salta aos olhos no fato de que, quatro anos depois, o mesmo aparecia em segunda edição, revista e ampliada (Gomes, 1972). As observações pastorais contidas neste texto apontam para a necessidade de uma "adaptação" litúrgica da igreja católica à realidade da população mais propensa a aceitar as práticas afro-brasileiras. Os freis Boaventura Kloppenburg e Raimundo Cintra falam mesmo da necessidade de uma "aculturação da liturgia católica aos nossos ambientes populares e de favela." (Gomes, Op.cit., p. 75). Ao lado dessa necessária inserção litúrgica, levando em consideração os valores celebrados nas religiōes afro-brasileiras, continuava, contudo, a condenação taxativa ao que denominavam de sincretismo religioso. Assim, o Ensaio de uma nova posição pastoral perante a umbanda, na verdade, um resumo de um artigo de Boaventura Kloppenburg publicado em 1968, afirma:

Respeitando, fomentando, elevando e consumando em Cristo tudo o que na umbanda descobrimos de bom, não esqueceremos, contudo, os pontos em 
que estão em desacordo com a doutrina da igreja e devem ser libertados de contágios malignos. Aliás, a umbanda não é só tradição africana, mas sincretismo. E o concilio não quer abrir portas ao sincretismo. Pelo contrário, sublinha ser necessário afastar toda a espécie de sincretismo e falso particularismo. Deve-se evitar o falso irenismo. O sincretismo com o espiritismo kardecista levou os umbandistas à prática da necromancia ou evocação dos mortos, e à doutrina da reencarnação. O fetichismo (africano e indígena), que continua quase intacto e puro na umbanda, transforma muitas de suas práticas em verdadeiros atos de magia (inclusive magia negra nos terreiros de quimbanda). Ora, a magia, a necromancia e o reencarnacionismo são práticas e doutrinas inconciliáveis com a vida e a mensagem cristã. Nesses pontos haveria, pois, um vasto e delicado campo de trabalho e purificação no ambiente umbandista. (Gomes, Op.cit., p. 87-88. Sem marcas no original).

Já o Padre Francisco Sparta faz uma leitura curiosa do sincretismo religioso. Segundo o preconizado pelo Vaticano II, reconhecia uma possibilidade de enriquecimento do catolicismo no possível contato com o "espírito-umbandismo". Contudo, para o sacerdote, a valorização litúrgica da realidade afro-ameríndia poderia "contaminar" e "adulterar" o catolicismo com conteúdos alienantes, capazes de dificultarem sua mensagem libertadora:

A lei do sincretismo, ou ao menos a tendência para o sincretismo (todas as religiōes, com exceção da cristã, têm-na aceito) leva as formas dominantes a se contaminarem, também elas, com elementos das inferiores. Está aí uma advertência, especialmente em época ecumênica, de que o catolicismo em contato com o espírito-umbandismo possa ficar enriquecido, mas também adulterado... Isto posto, as alternativas litúrgicas são, ou a criação para certas faixas do povo, de uma liturgia até certo ponto inspirada nos moldes dos cultos umbandistas; ou a revitalização de velhas paraliturgias e a invenção de novas, segundo o exemplo dos antigos evangelizadores de nosso povo. Não ocultaremos, porém, e deixaremos à livre discussão, as objeções a essas duas soluçōes. Uma liturgia com ritmos e nênias afro-indias pode adormecer ainda mais a consciência que o povo deve ter de seus males, e tirar-lhe a vontade de lutar por uma vida e uma sociedade melhores. (Gomes, Op.Cit., p. 92. Sem marcas no original) 
A dificuldade com que a hierarquia católica tratava da questão do que entendia por sincretismo religioso, ainda na primeira década pós-concílio Vaticano II, evidencia, ao lado da complexidade do assunto, a presença de um clero bastante preso a uma igreja, que enfatizava o magistério e se mostrava pouco sensível a uma realidade axiológica que não passasse pelo crivo do mesmo. O próprio magistério da igreja conciliar, de maneira clara, apresentava o sincretismo como realidade a ser combatida. Assim, em 1965, o papa Paulo VI asseverava:

Toda a aparência de sincretismo e de falso particularismo, será assim excluida, a vida cristã conformar-se-á bem ao gênio de cada cultura, as tradiçôes particulares e qualidades próprias de cada nação, esclarecidas pela luz do Evangelho, serão assumidas na unidade católica. (Decreto, 1965. Sem marcas no original)

Do elogio à "carteira de católico" haitiana do período pré-conciliar à defesa de uma "aculturação", onde a aceitação da realidade afro-ameríndia salientasse as "sementes de evangelização" nelas existentes, típicas do pósVaticano II, fugindo, contudo, dos "irenismos" e das "contaminaçôes", afirmava-se uma realidade de longa duração no discurso da hierarquia católica brasileira. Permanecia a insensibilidade para pensar o povo brasileiro a partir da porosidade identitária que o formou (Sanchis, 1995). Esta realidade de longa duração, igualmente, impossibilitou a hierarquia católica de pensar a nação fora da associação com o catolicismo (Pierucci, 2004) e a reconhecer a capacidade do povo em viver inserido em lógicas e temporalidades concomitantes. Para muito além da hierarquia próxima a Varnhagen das décadas pré-conciliares, mesmo alguns representantes da teologia da libertação acabaram conservando uma representação da nacionalidade centrada num "idioma único" católico (Pierucci, Op.Cit.). Percebemos, assim, mesmo em um passado mais próximo, a permanência de um olhar no qual o reconhecimento de uma "essência católica" chocou-se com transformações históricas e processos de identificação capazes de colocar em xeque a própria noção de sincretismo. 


\section{REFERÊNCIAS}

ALENCAR, José de. O Guarani. Rio de Janeiro: Otto Pierre Editores, 1979. [1857]

BAPTISTA, D. José Newton de Almeida. A palavra do Pastor. Brasília, n. $1,1974$.

BOURDIEU, Pierre. Economia das trocas lingüisticas. São Paulo: Editora da USP, 1996.

CANABRAVA, Alice. Apontamentos sobre Varnhagen e Capistrano. Revista de História. São Paulo: USP, v. 18, n. 88, p. 417-424, out./dez. 1971.

. História Econômica: estudos e pesquisas. São Paulo: Hucitec, 2005.

CARVALHO, José Murilo de. Pontos e bordados. Escritos de história e politica. Belo Horizonte: Editora da UFMG, 1992.

CEZAR, Temístocles. Varnhagen em movimento: breve antologia de uma existência. Topoi. v. 8, n. 15, p. 159-207, 2007.

CHAUÍ, Marilena. Brasil. Mito fundador e sociedade autoritária. São Paulo: Fundação Perseu Abramo, p. 9, 2000.

CONFERENCIA GENERAL DEL EPISCOPADO LATINOAMERICANO. Conclusiones. Vaticano:Tipografia Poliglota Vaticana, 1956.

CORREA, Dom Francisco de Aquino. Hino do Primeiro Congresso Eucarístico Nacional. Mensageiro do Coração de Jesus. v. 39, n. 448, p. 561, 1933.

. Discursos. Rio de Janeiro: Imprensa Nacional, 1944.

DECRETO AD GENTES. 07/12/1965. Disponível em: http://www. vatican.va/archive/hist_councils/ii_vatican_council/documents/vat-ii_ decree_19651207_ad-gentes_po.html Acesso em: 30 de ago. 2010. 
EPISCOPADO BRASILEIRO. Carta Pastoral do Episcopado Brasileiro ao clero e aos fiéis de suas dioceses por ocasião do Centenário da Independência. Rio de Janeiro: Papelaria e Tipografia Marques, Araujo \& Companhia, 1922.

FREYRE, Gilberto. Casa grande e senzala: formação da família brasileira sob o regime da economia patriarcal. Rio de Janeiro: José Olympio, 1975. FRIDERICHS, Pe. Edvino. Onde os espiritos baixam. Orientação para os católicos sobre espiritismo, umbanda e charlatanismo. São Paulo: Edições Paulinas, 1965.

GOMES, D. Cirilo Folch (Coord.). Macumba, cultos brasileiros, candomblé, umbanda. Observações pastorais. São Paulo: Paulinas, 1976.

GOMES, Alfredo Dias. O pagador de promessas. Rio de Janeiro: Ediouro, 2005. GUIMARÃES, Lúcia Paschoal. Francisco Adolpho de Varnhagen. In: MOTA, Lourenço Dantas (Org.). Introdução ao Brasil: Um banquete no trópico 2. São Paulo: Editora SENAC, 2002.

ISAIA, Artur Cesar. A hierarquia católica brasileira e o estado português. In: SZESZ, Christiane M. et al. (Orgs.). Portugal-Brasil no século XX. Sociedade, cultura e ideologia. Bauru: EDUSC, 2003a.

. Catolicismo e ordem republicana no Brasil. In: RIBEIRO, Maria Manuela Tavares (Coord.). Portugal-Brasil. Uma visão interdisciplinar do século XX. Coimbra: Centro de Estudos Interdisciplinares do Século XX, da Universidade de Coimbra, 2003b.

- Onde os espiritos baixam. A obra do Padre Friderichs e o discurso católico sobre as religióes mediunicas no periodo conciliar. Comunicação apresentada na XXII Reunião Anual da SBPH, Curitiba, PR, 2002 (mimeo). KLOPPENBURG, Boaventura. A umbanda no Brasil. Petrópolis: Vozes, 1961.

1960.

. O espiritismo no Brasil: orientação aos católicos. Petrópolis: Vozes, 
. É alarmante o crescimento do baixo espiritismo no Brasil. Revista Eclesiástica Brasileira. v. 13, n. 2, p. 416-420, 1953.

. Congados. Revista Eclesiástica Brasileira. v. 19, n. 3, p. 654-655, 1959.

MAGGIE, Yvonne. Medo do feitiço: relações entre magia, poder e ritual. Rio de Janeiro: Arquivo Nacional, 1992.

MELO, Gladstone Chaves de. Relações entre literatura e ambiente. Vozes de Petrópolis, jan./fev., 1942.

MOTTA, D. Carlos Carmelo de Vasconcelos. Panorama religioso do Brasil no XXXVI Congresso Eucarístico Internacional. Boletim Eclesiástico, jul./ ago. 1955.

. Combate ao Espiritismo. Boletim Eclesiástico, jul./ago., 1953.

NINA RODRIGUES, Raymundo. As coletividades anormais. Rio de Janeiro: Civilização Brasileira, 1939.

Brasileira, 1935.

. O animismo fetichista dos negros baianos. Rio de Janeiro: Civilização

NOGARA, Constâncio. Solene bênção da nova capital da república. Revista Eclesiástica Brasileira. v. 20, n. 2, p. 375-378.

PIERUCCI, Antônio Flávio; PRANDI, Reginaldo. A realidade social das religiôes no Brasil. São Paulo Hucitec, 1996.

PIERUCCI, Antônio Flávio. Bye Bye Brasil - o declínio das religiōes tradicionais no censo 2000. Estudos Avançados. v. 18, n. 52, p. 17-25, 2004.

PLUTARCO. De l'amitié fraternelle. In: Oeuvres morales de Plutarque. Paris: Didier, 1844. Disponível em: http://books.google.com.br/ books?id=IWJEAAAAMAAJ\&pg. Acesso em: 20 de ago. 2010.

POULAT, Émile. Compreensão histórica da igreja e compreensão eclesial da história. Concilium. v. 5, n. 5, p. 811-824, 1971. 
PRANDI, Reginaldo. Segredos guardados: Orixás na alma brasileira. São Paulo: Companhia das Letras, 2005.

REIS, José Carlos. Varnhagen: o elogio da colonização portuguesa. In: REIS, José Carlos. As identidades do Brasil: de Varnhagen a FHC. Rio de Janeiro: Fundação Getúlio Vargas, 2000.

RIBEIRO, Renilson Rosa. A questão do outro e os livros didáticos. Revista Fatos \& Versóes. v. 2, n. 4, p. 75-88, 2010.

SANCHIS, Pierre. Arraial: festa de um povo - as romarias portuguesas. Lisboa: Publicações Dom Quixote, 1983.

. O campo religioso será ainda hoje o campo das religióes? In: HOORNAERT, Eduardo. História Geral da Igreja na América Latina e no Caribe (1945-1995). Petrópolis: Vozes, 1995.

SELL, Carlos Eduardo; BRUSEKE, Franz Josef. Mistica e sociedade. São Paulo: Paulinas, 2006.

SERRANO, Jônatas. Sacerdos Magnus. In: SERRANO et al. Festas Jubilares e Sacerdotais (1914-1926). [snt].

SILVA, D. Augusto Álvaro da. Pastoral. Salvador: Era Nova Ltda., 1950.

VARNHAGEN, Francisco Adolfo de. História geral do Brasil, por um sócio do Instituto Histórico e Geográfico do Brasil. Madrid: Imprensa da V. de Dominguez, 1854.

WERNET, Augustin. A igreja paulista no século XIX. São Paulo: Ática, 1987. WISNIK, Guilherme. Lúcio Costa. São Paulo: Cosac e Naify, 2001. 